Research Article

\title{
Co-Solvent Free Electrochemical Synthesis of Biodiesel Using Graphite Electrode and Waste Concrete Heterogeneous Catalyst: Optimization of Biodiesel Yield
}

\author{
Wiyogo Prio Wicaksono, ${ }^{1,2, *)}$, Sekar Asmara Jati ${ }^{1,2}$, Ika Yanti ${ }^{1}$, Prastika Krisma Jiwanti ${ }^{3}$ \\ ${ }_{1}$ Department of Chemistry, Faculty of Mathematics and Natural Sciences, Universitas Islam Indonesia, \\ Jl. Kaliurang KM 14.5, Yogyakarta, 55584, Indonesia. \\ ${ }_{2}^{2}$ Research Center for Materials and Electrochemistry, Faculty of Mathematics and Natural Sciences, \\ Universitas Islam Indonesia, Jl. Kaliurang KM 14.5, Yogyakarta, 55584, Indonesia. \\ ${ }^{3}$ Nanotechnology Engineering, Faculty of Advanced Technology and Multidiscipline, Universitas \\ Airlangga, Kampus C Universitas Airlangga, Surabaya, 60115, Indonesia.
}

Received: $8^{\text {th }}$ February 2021; Revised: 23rd March 2021; Accepted: 23rd March 2021 Available online: 25th March 2021; Published regularly: March 2021

\section{Abstract}

This study optimized a co-solvent free electrochemical method for biodiesel synthesis using graphite electrode and waste concrete heterogeneous catalyst. Various parameters were evaluated, including: applied voltage (9.6, 14.4, $19.2 \mathrm{~V}$ ), catalyst particle size uniformity (unfiltered and filtered with 150 mesh), and reaction time (15, 30, 120, $240 \mathrm{~min}$ ). The results obtained $100 \%$ FAME content and $78.51 \%$ of biodiesel yield that were achieved at $14.4 \mathrm{~V}$ within 30 min using filtered catalyst and cooking oil feedstock. However, a slight decline was observed with the use of waste cooking oil. This optimized method offers a reliable and simple condition for mass biodiesel production.

Copyright (C) 2021 by Authors, Published by BCREC Group. This is an open access article under the CC BY-SA License (https://creativecommons.org/licenses/by-sa/4.0).

Keywords: Electrochemical Synthesis; Biodiesel; Waste Concrete; Heterogeneous Catalyst; Waste Cooking Oil

How to Cite: W.P. Wicaksono, S.A. Jati, I. Yanti, P.K. Jiwanti (2021). Co-Solvent Free Electrochemical Synthesis of Biodiesel Using Graphite Electrode and Waste Concrete Heterogeneous Catalyst: Optimization of Biodiesel Yield. Bulletin of Chemical Reaction Engineering \& Catalysis, 16(1), 179-187 (doi:10.9767/bcrec.16.1.10310.179187)

Permalink/DOI: https://doi.org/10.9767/bcrec.16.1.10310.179-187

\section{Introduction}

Biodiesel remains a significant eco-friendly and alternative renewable energy source [1], particularly in developing countries [2]. In meeting the huge national demand, a larger preference for the feedstock, including palm oil and the derivatives, e.g. waste cooking oil (WCO), are also considered. Previous studies

* Corresponding Author.

Email: wiyogo.prio@uii.ac.id (W.P. Wicaksono);

Telp: +62-74- 895920 ext 3012, Fax: +62-74- 896439 widely regarded WCO utilization as a very suitable raw material and energy resource, as well as a possible solution to waste problems [3-5].

Among the available biodiesel production methods, electrochemical synthesis (electrosynthesis / electrolysis) offers great benefits, termed ready conducted at ambient conditions, suitable for oil feedstock with high water content, less operational energy, no co-solvent required, and high possibility to enhance optimal performance by heterogeneous catalyst addition [3,6], including carbon@chitosan compo- 
site [7], chitosan gel [8], $\mathrm{CaO}$ from eggshell [6], zeolite/chitosan composite [9]. Meanwhile, graphite electrodes were applied in this research due to cheap and excellent conductivity properties of carbon-based materials [10].

Our previous study reported the utilization of waste concrete could enhance the performance of biodiesel electrosynthesis by producing biodiesel with FAME content up to $98.37 \%$ using $0.5 \mathrm{wt} . \%$ of the catalyst at $9.6 \mathrm{~V}$ for $2 \mathrm{~h}$ [3]. This high result recognized the electrosynthesis as a very promising approach with the need for further development, and also with potentials to meet the minimum European and Indonesian standard (96.5\%), without additional purification $[11,12]$. Furthermore, the study also reported that the amount of catalyst influenced the FAME content produced [3]. Unfortunately, to obtain optimized condition, the applied voltage, catalyst particle size uniformity, and reaction time were not comprehensively evaluated.

In this study, the effect of applied voltage, the uniformity of catalyst particle size, as well as the reaction time were investigated. The electric current flow in the electrolytic cell was also investigated for all experiments. All of the synthesized biodiesels were analyzed using gas chromatography-mass spectrometry (GC-MS) to calculate the FAME content as well as the biodiesel yield. Furthermore, the evaluation of physicochemical characteristic i.e., water and free fatty acid (FFA) content in the cooking oil feedstock were also evaluated.

\section{Materials and Methods}

\subsection{Materials}

The vegetable (cooking) oil containing palm oil, was purchased from the mini market in Yogyakarta, while WCO was obtained from home industries around Universitas Islam Indonesia, Indonesia. $\mathrm{NaOH}$ (p.a.) and methanol (pa) were purchased from Merck, while $\mathrm{NaCl}$ (>99\%) was purchased from PT UniChemCandi Indonesia. Waste concrete was supplied from building restoration around Universitas Islam Indonesia, Indonesia, without any pretreatment.

\subsection{Oil Feedstock Characterization}

In evaluating cooking oil and WCO qualities, water and FFA contents were analyzed using gravimetric and titration methods, respectively, based on the National Standardization of Indonesia (SNI) [3]. A brief water content analysis was conducted, where a sample holder was dried for $30 \mathrm{~min}$ in the oven $(130 \pm 1){ }^{\circ} \mathrm{C}$ and then cooled down $\left(W_{0}\right)$. Subsequently, $2 \mathrm{~g}$ of oil was added to a vessel $\left(W_{1}\right)$, followed by further drying at similar temperature, and also left to be cooled down $\left(W_{2}\right)$. This procedure was repeated until $W_{2}$ achieved equilibrium. Furthermore, the water content (\%) was calculated using the Eq. (1):

$$
\text { water content } \%=\frac{W_{1}-W_{2}}{W_{1}-W_{0}} \times 100 \%
$$

with $W_{0}$ is the weight of blank sample holder (g), $W_{1}$ and $W_{2}$ are the weight of sample holder contains oil sample before and after drying (g), respectively.

Meanwhile, for FFA analysis, $10 \mathrm{~g}$ of oil was diluted in $50 \mathrm{~mL}$ of warm ethanol, followed by the addition of 5 drops of PP indicator. A $0.1 \mathrm{M}$ $\mathrm{NaOH}$ served as a titrant in the acid-base titration, where a color change to pink was observed at equilibrium. The FFA (as palmitic acid) was calculated using the Eq. (2):

$$
\text { free fatty acid }(F F A) \%=\frac{25.6 \times V \times N}{W}
$$

where, the value of the constant is $25.6, V$ and $N$ represent the volume $(\mathrm{mL})$ and normality (N) of $\mathrm{NaOH}(\mathrm{mL})$, while $\mathrm{W}$ refers to the oil sample weight (g).

\subsection{Optimization of the Condition of Biodiesel Electrosynthesis}

The biodiesel electrosynthesis was conducted using a constant DC voltage (Sanfix SP$305 \mathrm{E})$ in line with previous report $[3,13]$. Briefly, a single chamber electrolytic cell equipped with two graphite electrodes $\left(3.52 \mathrm{~cm}^{2}\right.$ of active surface area) were separated by $12 \mathrm{~mm}$, with a $30 \mathrm{~mL}$ solution containing cooking oil and methanol (1:24 molar ratio), deionized water (0.1 wt\% of entire mixture weight), and $\mathrm{NaCl}$ ( $0.56 \mathrm{wt} \%$ of oil weight) as the electrolyte. A 0.5 $\mathrm{wt} \%$ of waste concrete (based on oil weight) was selected as the optimum heterogeneous catalyst weight, as reported in previous result [3]. The effects of applied voltage (9.6, 14.4, and $19.2 \mathrm{~V}$ ), catalyst particle size uniformity (unfiltered and filtered by $150 \mathrm{mesh}$ ), and reaction time $(15,30,120$, and $240 \mathrm{~min})$ were evaluated. Furthermore, the electric current flow in electrolytic cell was also monitored. The overall synthesis was conducted at ambient condition under constant stirring, without any co-solvent. Subsequently, the optimized condition was employed with WCO as feedstock. 


\subsection{Biodiesel Characterization}

The biodiesel product (top) was immediately separated from the final mixture. In addition, GC-MS (Shimadzu QP 2010 equipped with Rtx5MS column) and a flame ionization detector (FID) were employed to evaluate the chemical composition, with helium as the carrier gas. A $0.1 \mathrm{~mL}$ of oil sample was injected, as the split inlet temperature and flow were retained at $250{ }^{\circ} \mathrm{C}$ and $30.8 \mathrm{~mL} \mathrm{~min}{ }^{-1}$, respectively. The column heat was operated at $80^{\circ} \mathrm{C}$, but subsequently climbed to $300{ }^{\circ} \mathrm{C}$. This state was maintained for 5 min and the yield (\%) was calculated using the following equation (Eq. (3)) $[2,14]$ :

yield $(\%)$ of biodiesel $=\frac{\text { mass of biodiesel produced }(g)}{\text { mass of initial oil }(g)} \times$ FAME content $(\%)$

The FAME content (\%) was determined by the sum of FAME \% area from the product chromatogram.

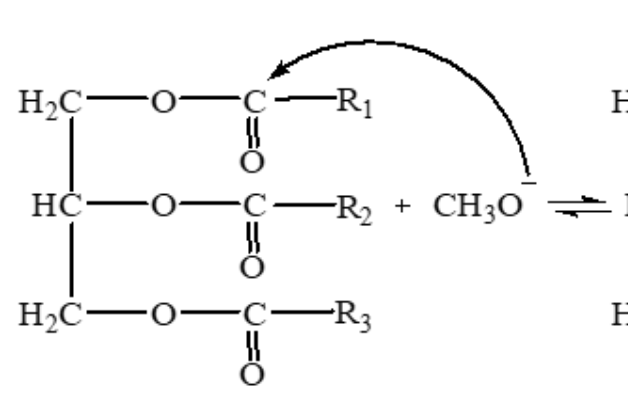

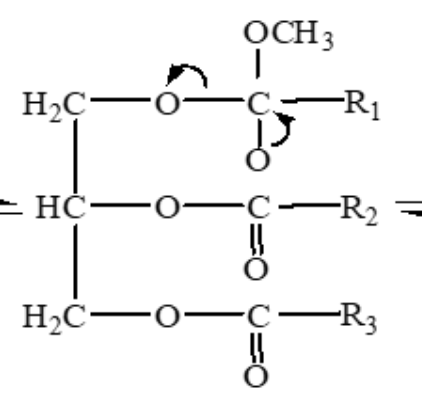<smiles>[R]C(=O)OC[C@@H](C[O-])OC([R1])=O</smiles>

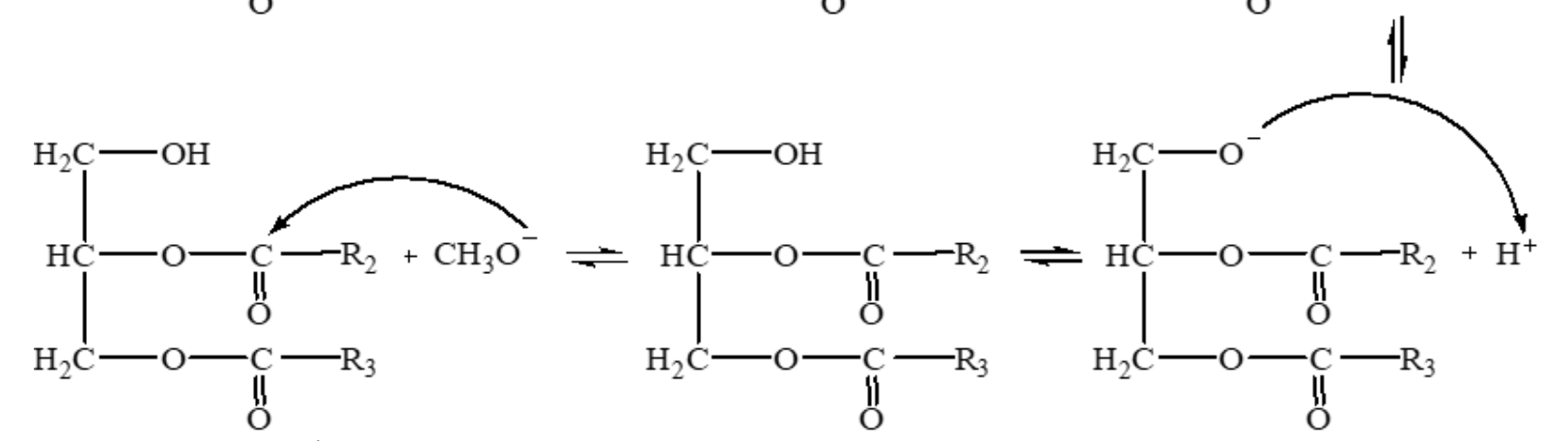<smiles>[R]C(=O)OCC(CO)OC([R])([R])OC</smiles><smiles>[R3]C(=O)OC[C@@H]([O-])CO</smiles><smiles>[R]C(=O)OC</smiles><smiles>[R3]C(=O)OC[C@@H](CO)[OH+]CCC[PH2+]</smiles><smiles>C=[R]C(=O)OC</smiles><smiles>[R3]C([R3])(OC)OCC(O)CO</smiles><smiles>[R3]C([R3])(CCCC[CH2-])OC[C@@H](O)CO</smiles><smiles></smiles><smiles>C=C</smiles><smiles>OCC(O)CO</smiles>

Figure 1. The transesterification reaction in the biodiesel synthesis. 


\section{Results and Discussion}

\subsection{Electrosynthesis of Biodiesel}

The biodiesel synthesis was conducted in a single electrolytic cell containing oil, methanol, $\mathrm{NaCl}$, water, and concrete waste rich-metal oxide (-M-O-), using graphite electrodes [3], due to low cost, inertness, good electrical conductivity, physical-chemical stability and durability [15]. The electrode provides comparable properties with other precious metals, such as platinum (Pt) and stainless steel (SS) that have been utilized in biodiesel synthesis $[13,16]$. The redox reaction on the electrodes are as follow (Eqs. $(4,5))$ :

$$
\begin{aligned}
& \text { Anode }: 2 \mathrm{H}_{2} \mathrm{O}_{(\mathrm{l})} \rightarrow 4 \mathrm{H}^{+}{ }_{(\mathrm{aq})}+4 \mathrm{e}+\mathrm{O}_{2}(\mathrm{~g}) \\
& 2 \mathrm{Cl}^{-}(\mathrm{aq}) \rightarrow \mathrm{Cl}_{2(\mathrm{~g})}+2 \mathrm{e} \\
& \text { Cathode: } 2 \mathrm{H}_{2} \mathrm{O}_{(\mathrm{l})}+2 \mathrm{e} \rightarrow 2 \mathrm{OH}^{-}{ }_{(\mathrm{aq})}+\mathrm{O}_{2} \text { (g) }
\end{aligned}
$$

The water electrolysis generated $\mathrm{H}^{+}$and $\mathrm{OH}^{-}$at anode and cathode that could act as acid and base catalyst for the esterification and transesterification reaction in the biodiesel synthesis, respectively. Meanwhile, the addition of concrete waste that could lead the protonation of water to produce surface $\mathrm{OH}^{-}$that will en-
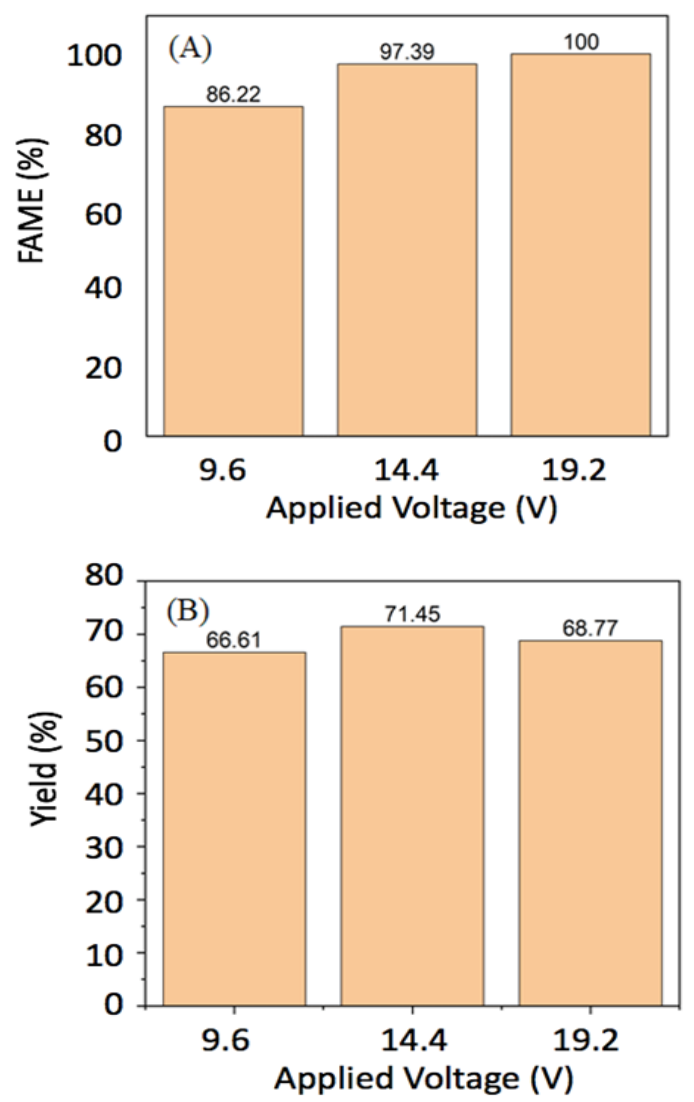

hance the catalytic activity (Eq. (6)) [17-19].

$$
-\mathrm{M}-\mathrm{O}-+\mathrm{H}-\mathrm{O}-\mathrm{H} \leftrightarrow-\mathrm{M}\left(\mathrm{OH}^{-}\right)-\mathrm{O}\left(\mathrm{H}^{+}\right)-
$$

The $\mathrm{OH}^{-}$from both water electrolysis and water protonation by waste concrete concurrently extracted the $\mathrm{H}^{+}$from methanol to produce methoxide $\left(\mathrm{CH}_{3} \mathrm{O}^{-}\right)$(Eq. (7)). This species was subsequently employed in the transesterification reaction by the following mechanism (Figure 1).

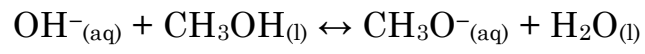

\subsection{The Effect of Applied Voltage}

Figure 2 shows the effects of applied voltage on FAME (\%) and biodiesel yield (\%), where the FAME content increased with the increasing of applied voltage and reached up to $100 \%$ at $19.2 \mathrm{~V}$. The result was linear with the previous report [6]. The increase in applied voltage will improve the electric current as well as the conductivity in the electrolytic system which led to the more extensive $\mathrm{OH}^{-}$generation in the cathode [13]. This trend was also projected for biodiesel yield (\%) [6], but unfortunately, a decline to $68.77 \%$ was observed at high applied voltage of $19.2 \mathrm{~V}$. It is due to the high voltage that decreased the electrode stability, led to the decrease of the conductivity as well as the electric current as shown in Figure 2C. Thus, the applied voltage of $14.4 \mathrm{~V}$ was employed for all further experiments.

\subsection{The Effect of the Uniformity of Catalyst Particle Size}

The effects of catalyst particle size uniformity of waste concrete on FAME content (\%) and biodiesel yield (\%) were evaluated. Figure 3A depicts high FAME up to $100 \%$ with filtered

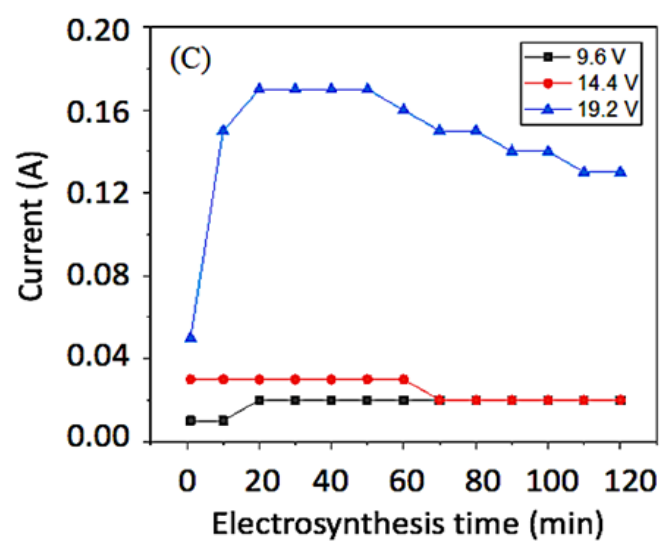

Figure 2. The FAME content (\%) (A) and yield (\%) (B) of biodiesel produced at various applied voltages (V); and the electric current recorded (C) for $2 \mathrm{~h}$ reaction. 
catalyst, but with unfiltered catalyst, a minor decline to $97.39 \%$ was observed. The uniform size of the catalyst promotes the reactants to effectively adsorb on the catalyst surface then react with other reactants to generate products. The catalyst with uniform size provides a higher effectiveness factor in the catalytic process compared to the non-uniform size [19]. Furthermore, the non-uniform catalyst provided
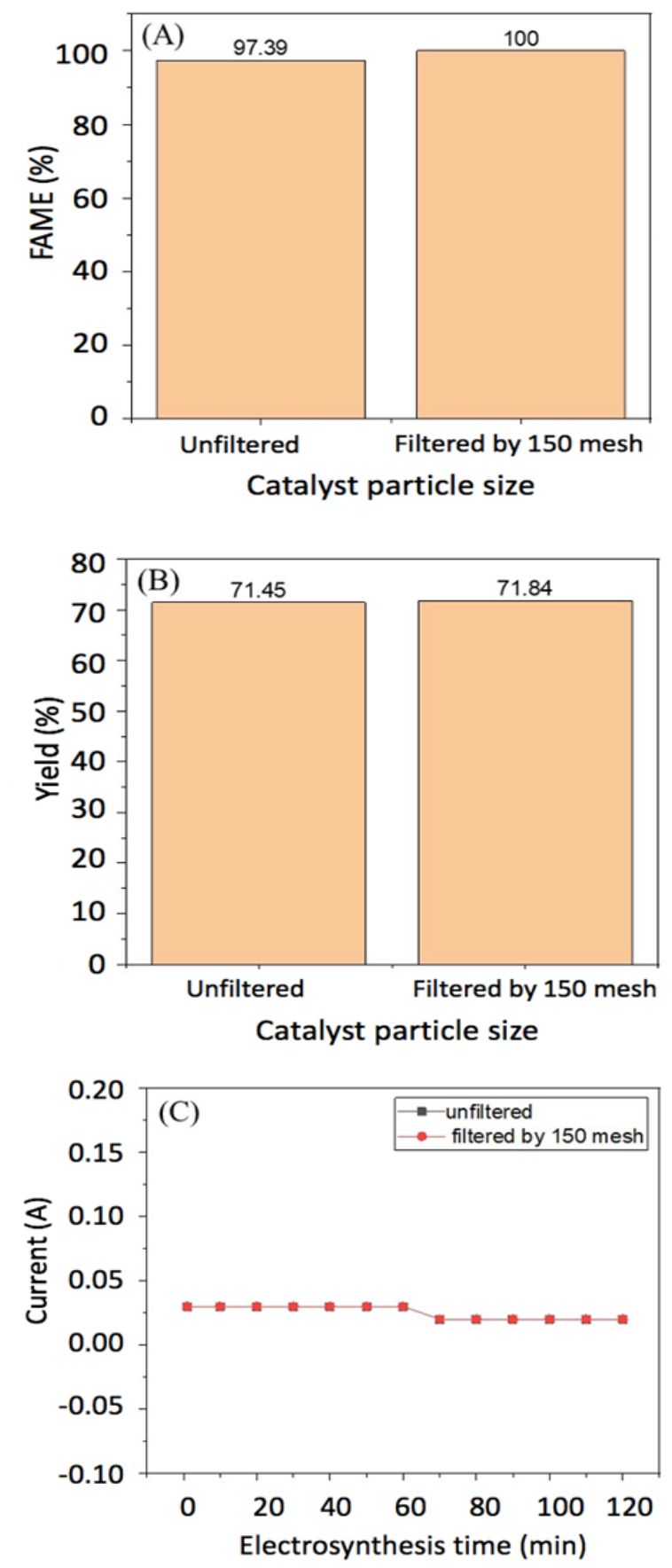

Figure 3. The FAME content (\%) (A) and yield (\%) (B) of biodiesel produced using unfiltered and filtered catalyst; and the electric current recorded $(\mathrm{C})$ for $2 \mathrm{~h}$ reaction. various active sites and was not able to completely control selectivity, leading to various products [20]. As a consequence, these variations did not significantly influence the biodiesel yield and electric current (Figure 3B and C). It is due to the only slight difference in uniformity of the filtered and the unfiltered catalyst particle. Therefore, the filtering treatment using 150 mesh was employed for further analysis.

\subsection{The Effect of Reaction Time}

The reaction time plays a significant role in the optimization process. Generally, the longer
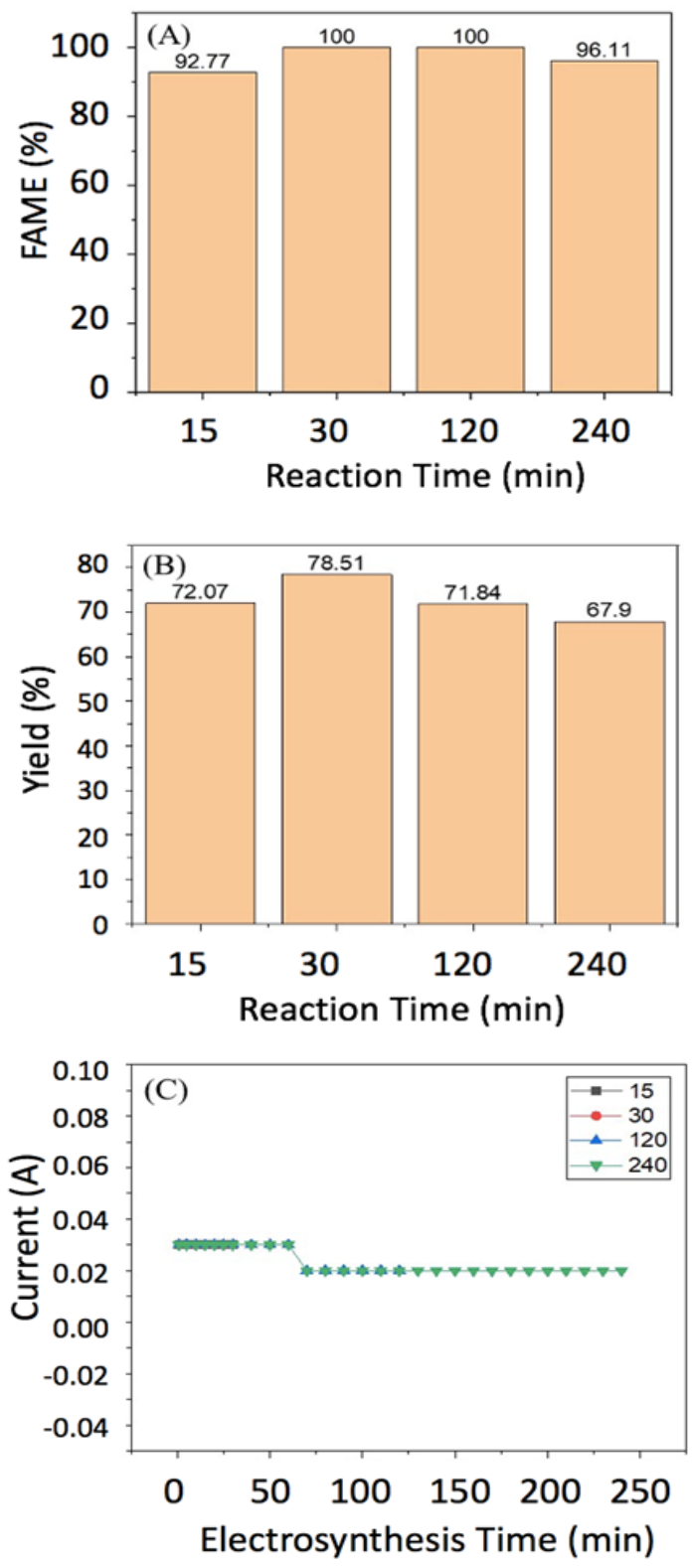

Figure 4. The FAME content (\%) (A) and yield (\%) (B) of biodiesel produced at various reaction time; and the electric current recorded (C). 
reaction time provides the reactant to collide with each other resulting in more products. Also, FAME is expected to increase as the reaction time continues to reach the equilibrium [21]. Figure 4A shows the reaction time of FAME content at 15, 30, 120, and $240 \mathrm{~min}$. The FAME content increased with the increase in reaction time and reached up to $100 \%$ at 30 and $120 \mathrm{~min}$, then slightly decreased to $96.11 \%$ at $240 \mathrm{~min}$. The decrease may be ascribed to the further conversion of FAME to unwanted prod-
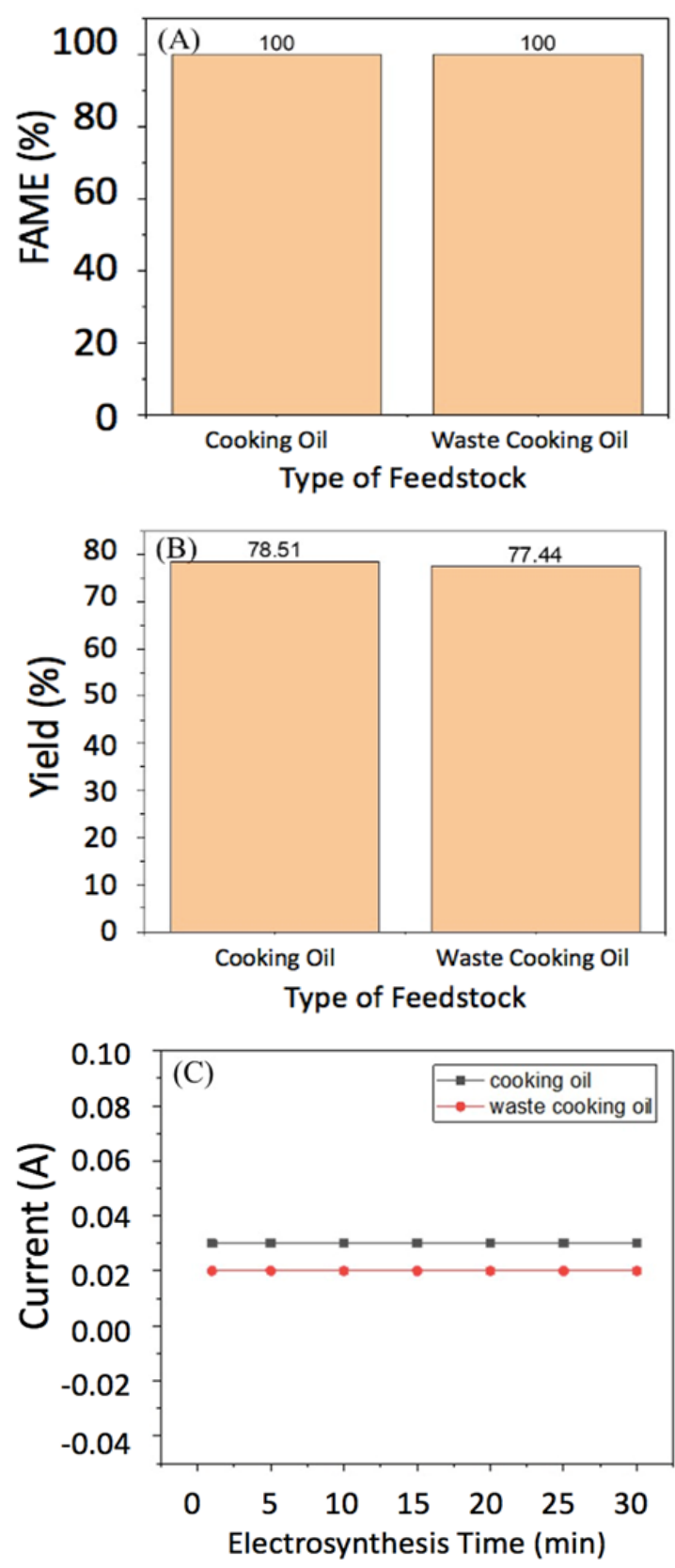

Figure 5. The FAME content (\%) (A) and yield (\%) (B) of biodiesel produced using waste cooking oil feedstock; and the electric current recorded (C). ucts, due to a long electrosynthesis process. Figure 4B shows the highest yield (\%) of biodiesel that was achieved at $30 \mathrm{~min}$, followed by a decline. It may due to the decrease of FAME content as well as the backreaction in the transesterification [22]. Additionally, the decrease of electric current in the electrolytic cell after 30 min reaction may be contributed to the decrease in yield, as shown in Figure 4C. Therefore, reaction time of $30 \mathrm{~min}$ reaction time was selected for the further investigation.

3.5 Evaluation of the Optimized Biodiesel Electrosynthesis Method Using WCO

The evaluation of optimized biodiesel electrosynthesis method was conducted with WCO feedstock. An applied voltage of $14.4 \mathrm{~V}$, filtered waste concrete catalyst, and $30 \mathrm{~min}$ reaction time were employed, based on the optimum previous condition. Figure 5A depicts FAME content up to $100 \%$ was achieved using both oil feedstocks, indicating that WCO has potential as feedstock for biodiesel synthesis. This result revealed that higher water content and FFA of WCO (Table 1) did not interfere the biodiesel electrosynthesis process, where commonly those high contents lead to a saponification reaction in the conventional biodiesel synthesis method [13]. A slight difference in FFA content between the cooking oil and the WCO indicates that the properties of WCO only slightly changed during the frying. This result was in agreement with the previous reports [23]. The FFA content generated by the hydrolysis reaction during the frying process primarily depends on the temperature, time, and mode of the frying process [23,24]. A higher frying temperature, longer frying time, as well as number of frying, resulted in a higher generation of FFA. Furthermore, the obtained yield (Figure 5B) was not significantly different for both feedstocks, whereas the slight decrease of the yield may be due to the more viscous character of WCO, leading the slower stirring process and the lower electric current (Figure 5C) [25]. Figure 6 and Table 2 represent the chromatograms of the synthesized biodiesel and chemical composition, respectively. Table 3 shows

Table 1. Physicochemical characteristic of biodiesel feed stocks.

\begin{tabular}{lcc}
\hline \multicolumn{1}{c}{ Parameter } & Cooking oil & $\begin{array}{c}\text { Waste } \\
\text { cooking oil }\end{array}$ \\
\hline Water content (\%) & 0.238 & 0.263 \\
FFA (\%) & 0.495 & 0.539 \\
\hline
\end{tabular}




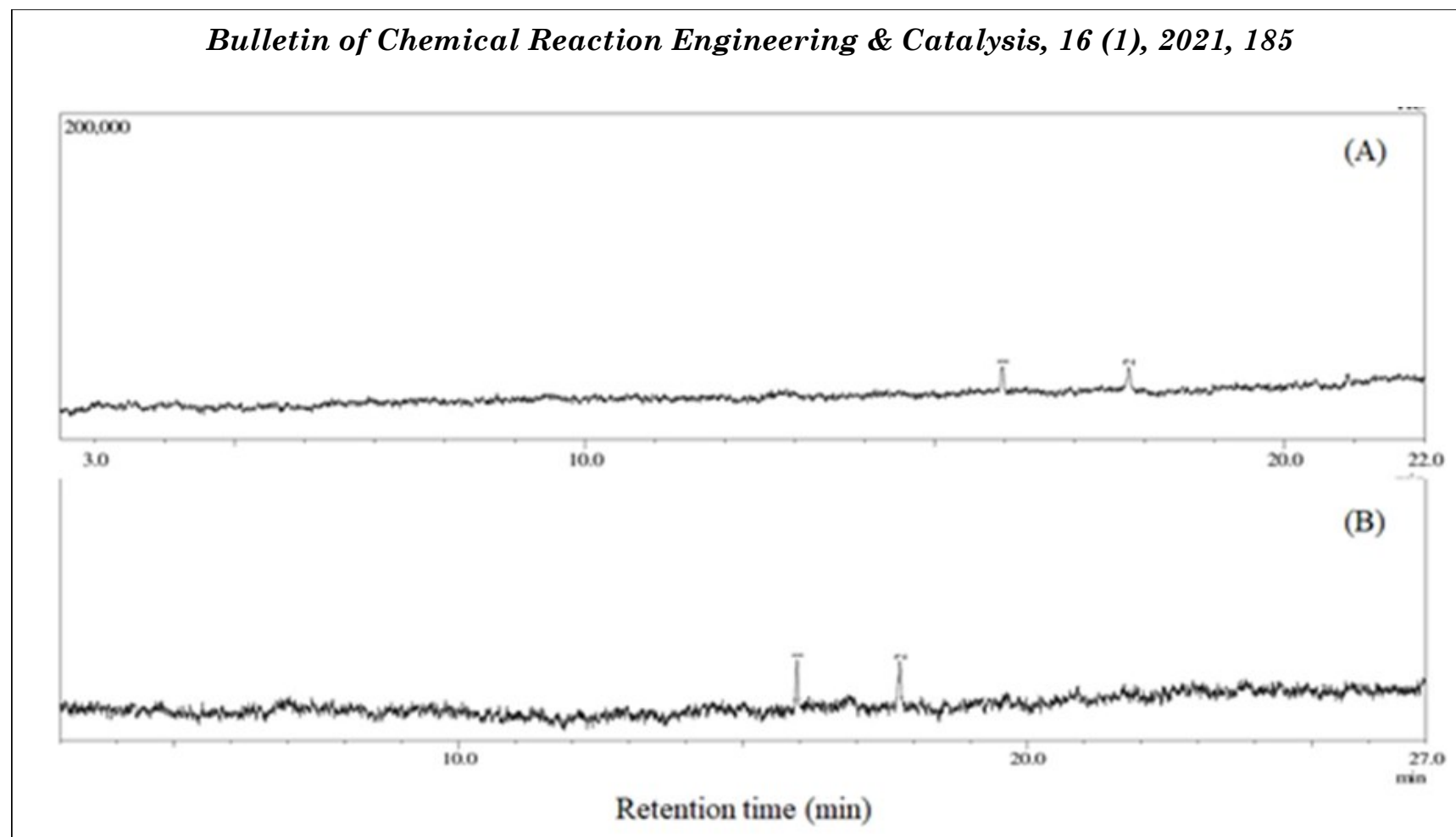

Figure 6. The chromatograms of the synthesized biodiesel with feedstock of: (A) cooking oil and (B) waste cooking oil.

Table 2. Chemical composition identification of the synthesized biodiesel using GC-MS.

\begin{tabular}{cccccc}
\hline $\begin{array}{c}\text { Biodiesel } \\
\text { feedstock }\end{array}$ & Peak & $\begin{array}{c}\text { Retention } \\
\text { time (min) }\end{array}$ & $\begin{array}{c}\text { Chemical } \\
\text { formula }\end{array}$ & Chemical compound & $\begin{array}{c}\text { Composition } \\
\text { (wt\%) }\end{array}$ \\
\hline & 1 & 15.969 & $\mathrm{C}_{17} \mathrm{H}_{34} \mathrm{O}_{2}$ & $\begin{array}{c}\text { Pentadecanoic acid, 14-methyl-, } \\
\text { methyl ester }\end{array}$ & 66.68 \\
Cooking oil & 2 & 17.771 & $\mathrm{C}_{20} \mathrm{H}_{38} \mathrm{O}_{2}$ & $\begin{array}{c}\text { Cyclopropanepentanoic acid, 2- } \\
\text { undecyl-, methyl ester, trans- }\end{array}$ & 33.32 \\
\hline $\begin{array}{c}\text { Waste } \\
\text { cooking oil }\end{array}$ & 1 & 15.954 & $\mathrm{C}_{17} \mathrm{H}_{34} \mathrm{O}_{2}$ & $\begin{array}{c}\text { Pentadecanoic acid, 14-methyl-, } \\
\text { methyl ester }\end{array}$ & $\begin{array}{c}61.20 \\
\text { Cyclopropanepentanoic acid, 2- } \\
\text { undecyl-, methyl ester, trans- }\end{array}$ \\
\hline
\end{tabular}

Table 3. Comparison of several biodiesel production methods.

\begin{tabular}{|c|c|c|c|c|c|c|c|}
\hline $\begin{array}{l}\text { Method/ Electrode } \\
\text { materials }\end{array}$ & $\begin{array}{l}\text { Applied } \\
\text { voltage } \\
\text { (V) }\end{array}$ & $\begin{array}{c}\text { Reaction } \\
\text { time } \\
\text { (min) }\end{array}$ & $\begin{array}{l}\text { Additional } \\
\text { catalyst }\end{array}$ & $\begin{array}{c}\text { Uniformity } \\
\text { catalyst } \\
\text { treatment }\end{array}$ & $\begin{array}{l}\text { FAME } \\
(\%)\end{array}$ & $\begin{array}{l}\text { Yield } \\
(\%)\end{array}$ & Ref. \\
\hline $\begin{array}{l}\text { Electrosynthesis/ } \\
\text { Graphite }\end{array}$ & 18.2 & 60 & $\begin{array}{l}\mathrm{CaO} \text { from } \\
\text { egg shell }\end{array}$ & No & 98.99 & N/A & {$[6]$} \\
\hline Microwave & - & 60 & $\begin{array}{l}\mathrm{SiO}_{2} \text { from } \\
\text { bamboo } \\
\text { leaves ash }\end{array}$ & No & N/A & 57.50 & [2] \\
\hline Conventional & - & 15 & $\mathrm{NaOH}$ & No & 99.93 & 61.79 & [26] \\
\hline $\begin{array}{l}\text { Ultrasound } \\
\text { irradiation }\end{array}$ & - & 15 & $\mathrm{KOH}$ & No & N/A & 62.77 & {$[28]$} \\
\hline Conventional & - & 240 & CaO-clay & No & N/A & 73 & {$[27]$} \\
\hline $\begin{array}{l}\text { Electrosynthesis/ } \\
\text { Graphite }\end{array}$ & 14.4 & 30 & $\begin{array}{c}\text { Waste } \\
\text { concrete }\end{array}$ & Yes & 100 & 78.51 & $\begin{array}{l}\text { This } \\
\text { work }\end{array}$ \\
\hline
\end{tabular}


the comparison of this method with other biodiesel production methods. This approach offered faster reaction time than microwave [2] and other biodiesel electrosynthesis method [6]. In addition, lower applied voltage was also observed [6]. In contrast to conventional [26,27] and ultrasound irradiation biodiesel synthesis [28], this research method showed the capacity to produce higher FAME content and biodiesel yield.

\section{Conclusions}

Optimizing conditions, including applied voltage, catalyst particle size uniformity, and reaction time of electrochemical biodiesel synthesis, have been successfully conducted in a single chamber electrolytic cell, using graphite electrodes and waste concrete catalyst. It was found that FAME content and the biodiesel yield increased with the increase of the applied voltage. Consequently, a decline was observed after achieving optimum voltage, due to electrode damage. The filtration phase offers the catalyst particle size uniformity known to influence the improvement of both FAME and biodiesel yield. The increase in reaction time up to 30 min could improve the FAME content and the yield, then declined for longer reaction. Moreover, the maximum FAME content and the biodiesel yield were achieved at applied voltage of $14.4 \mathrm{~V}$ in 30 min reaction time, using both cooking and waste cooking oils. It is suggested that high energy consumption and long reaction are not necessary to synthesize biodiesel by filtered waste concrete catalytic enhanced electrochemical method in ambient condition. Finally, an optimized process condition was achieved and is believed to be cost-effective for mass biodiesel production.

\section{Acknowledgments}

The author is grateful to the Integrated Laboratory of Universitas Islam Indonesia for assisting in GC-MS biodiesel characterization.

\section{References}

[1] Istadi, I., Anggoro, D.D., Marwoto, P., Suherman, S., Nugroho, B.T. (2009). Biodiesel production from vegetable oil over plasma reactor: optimization of biodiesel yield using response surface methodology, Bulletin of Chemical Reaction Engineering \& Catalysis, 4(1), 23-31, doi: 10.9767/bcrec.4.1.7115.23-31.

[2] Fatimah, I., Rubiyanto, D., Taushiyah, A., Badriatun, F., Azmi, U., Sim, Y. (2019). Use of $\mathrm{ZrO}_{2}$ supported on bamboo leaf ash as a heterogeneous catalyst in microwave-assisted biodiesel conversion. Sustainable Chemistry and Pharmacy, 12(100129), 1-8, doi: 10.1016/j.scp.2019.100129.

[3] Wicaksono, W.P., Marcharis, A.L., Sari, Y.P., Citradewi, P.W., Kadja, G.T.M. (2018). Highyield co-solvent free electrochemical production of biodiesel from waste cooking oil using waste concrete as heterogeneous catalyst. AIP Conference Proceedings, 2026(020068), 18, doi: 10.1063/1.5065028.

[4] Uddin, M.R., Ferdous, K., Uddin, M.R., Khan, M.R., Islam, M.A. (2013). Synthesis of biodiesel from waste cooking oil. Chemical Engineering and Science, 1(2), 22-26, doi; 10.12691/ces-1-2-2.

[5] Fereidooni, L., Tahvildari, K., Mehrpooya, M. (2018). Trans-esterification of waste cooking oil with methanol by electrolysis process using KOH. Renewable Energy, 116(Part A), 183-193, doi: 10.1016/j.renene.2017.08.067.

[6] Putra, R.S., Liyanita, A., Arifah, N., Puspitasari, E., Sawaludin, Hizam, M.N. (2017). Enhanced electro-catalytic process on the synthesis of FAME using $\mathrm{CaO}$ from eggshell. Energy Procedia, 105, 289-296, doi: 10.1016/j.egypro.2017.03.316.

[7] Putra, R.S., Antono, Y., Pratama, K. (2017). Carbon material@Chitosan composite as catalyst on the synthesis of FAME from usedcooking oil with electrocatalytic process. IOP Conference Series: Journal of Physics, 877(012063), 1-9, doi: 10.1088/17426596/877/1/012063.

[8] Putra, R.S., Pratama, K., Antono, Y., Idris, M., Rua, J., Ramadhani, H. (2016). Enhanced electrocatalytic biodiesel production with chitosan gel (hydrogel and xerogel). Procedia Engineering, $148, \quad 609-614$, doi: 10.1016/j.proeng.2016.06.522.

[9] Fereidooni, L., Mehrpooya, M. (2017). Experimental assessment of electrolysis method in production of biodiesel from waste cooking oil using zeolite/chitosan catalyst with a focus on waste biorefinery. Energy Conversion and Management, 147, 145-154, doi: 10.1016/j.enconman.2017.05.051.

[10] Abdollahi, M., Tahvildari, K., Bigdeli, T. (2020). Eco-friendly synthesis of biodiesel from WCO by using electrolysis technique with graphite electrodes. Fuel, 270(117582), 1-11, doi: 10.1016/j.fuel.2020.117582.

[11] Badan Standardisasi Nasional. (2015). SNI Biodiesel No. 7182:2015, 1-88.

[12] Rutz, D., Janssen, R. (2006). Overview and recommendations on biofuel standards for transport in the EU. Citing internet sources 
URL: https://ec.europa.eu/energy/intelligent/ $\mathrm{p}$ r o j e c t s / s i t e s / i e e projects/files/projects/documents/biofuel_marketplace_biofuel_standards_for_transport_in_ the_eu.pdf.

[13] Guan, G., Kusakabe, K. (2009). Synthesis of biodiesel fuel using an electrolysis method. Chemical Engineering Journal, 153, 159-163, doi: 10.1016/j.cej.2009.06.005.

[14] Handayani, P.A., Abdullah, A., Hadiyanto, H. (2017). Biodiesel production from nyamplung (Calophyllum inophyllum) oil using ionic liquid as a catalyst and microwave heating system. Bulletin of Chemical Reaction Engineering \& Catalysis, 12(2), 293-298, doi: 10.9767/bcrec.12.2.807.293-298.

[15] Yuvaraj, A.L., Santhanaraj, D. (2014). A systematic study on electrolytic production of hydrogen gas by using graphite as electrode. Materials Research, 17(1), 83-87, doi: 10.1590/S1516-14392013005000153.

[16] Allioux, F.M., Holland, B.J., Kong, L., Dumée, L.F. (2017). Electro-catalytic biodiesel production from canola oil in methanolic and ethanolic solutions with low-cost stainless steel and hybrid ion-exchange resin grafted electrodes. Frontiers in Materials, 4, 1-10, doi: 10.3389/fmats.2017.00022.

[17] Liu, X., He, H., Wang, Y., Zhu, S., Piao, X. (2008). Transesterification of soybean oil to biodiesel using $\mathrm{CaO}$ as a solid base catalyst. Fuel, $87, \quad 216-221, \quad$ d o i : 10.1016/j.fuel.2007.04.013.

[18] Boey, P.L., Maniam, G.P., Hamid, S.A. (2011). Performance of calcium oxide as a heterogeneous catalyst in biodiesel production: A review. Chemical Engineering Journal, 168, 15-22, doi: 10.1016/j.cej.2011.01.009.

[19] Rafael, J., María, C., Sedran, U. (2020). Nonuniform size of catalyst particles. Impact on the effectiveness factor and the determination of kinetic parameters. Chemical Engineering Journal, 396(124994), 1-11, doi: 10.1016/j.cej.2020.124994.

[20] Dumesic, J.A., Huber, G.W., Boudart, M. (2008). Handbook of Heterogeneous Catalysis. 2nd edition. Weinheim: Wiley-VCH Verlag $\mathrm{GmbH} \& \mathrm{Co}$. K GaA, doi : 10.1002/9783527610044.
[21] Okwundu, O.S., El-Shazly, A.H., Elkady, M. (2019). Comparative effect of reaction time on biodiesel production from low free fatty acid beef tallow: a definition of product yield. $S N$ Applied Sciences, 1(2), 1-12, doi: 10.1007/s42452-018-0145-1.

[22] Turnip, J.R., Tarigan, T.F.L., Sinaga, M.S. (2017). Effect of catalyst mass and reaction time on biodiesel production from waste cooking oil using heterogeneous catalyst $\mathrm{K}_{2} \mathrm{O}$ from waste cocoa peel ash. Teknik Kimia USU, 6(2), 24-29, doi: 10.32734/jtk.v6i2.1579.

[23] Sayyad, R. (2017). Effects of deep-fat frying process on the oil quality during French fries preparation. Journal of Food Science and Technology, 54(8), 2224-2229, doi: 10.1007/s13197-017-2657-x.

[24] Choe, E., Min, D.B. (2007). Chemistry of deep-fat frying oils. Journal of Food Science, $72(5), \quad 78-86, \quad$ doi: $10.1111 / \mathrm{j} .1750$ 3841.2007.00352.x.

[25] Kumar, D., Singh, A., Tarsikka, P.S. (2013). Interrelationship between viscosity and electrical properties for edible oils. Journal of Food Science and Technology, 50(3), 549-554, doi: 10.1007/s13197-011-0346-8.

[26] Julianto, T.S., Nurlestari, R. (2018). The effect of acetone amount ratio as co-solvent to methanol in transesterification reaction of waste cooking oil. IOP Conference Series: $M a-$ terials Science and Engineering, 349(012063), 1-5, doi: 10.1088/1757-899X/349/1/012063.

[27] Syukri, S., Septioga, K., Arief, S., Putri, Y.E., Efdi, M., Septiani, U. (2020). Natural clay of pasaman barat enriched by cao of chicken eggshells as catalyst for biodiesel production. Bulletin of Chemical Reaction Engineering \& Catalysis, 15(3), 662-673, doi: 10.9767/BCREC.15.3.8097.662-673.

[28] Irwan, M., Saidi, H., Rachman, M.A., Ramli, R., Marlinda, M. (2017). Rapid alcoholysis of Jatropha curcas oil for biodiesel production using ultrasound irradiation. Bulletin of Chemical Reaction Engineering \& Catalysis, 12 ( 3 ), $\quad 306-311, \quad \mathrm{~d}$ o i : 10.9767/bcrec.12.3.801.306-311.

Selected and Revised Papers from $3^{\text {rd }}$ International Conference on Chemistry, Chemical Process and Engineering 2020 (IC3PE 2020) (https://chemistry.uii.ac.id/ic3pe/) (Universitas Islam Indonesia (UII), Labuan Bajo, Nusa Tenggara Timur, Indonesia by 30th September - 1st October 2020) after Peer-reviewed by Scientific Committee of IC3PE 2020 and Peer-Reviewers of Bulletin of Chemical Reaction Engineering \& Catalysis.

Editors: I. Istadi; Is Fatimah 